\title{
PENUNDAAN PEMBERIAN PAKAN ARTEMIATERHADAP PERFORMANSI BENIH IKAN COBIA (Rachycentron canadum) YANG DIPELIHARA SECARA TERKONTROL
}

\author{
Titiek Aslianti, Afifah, dan Siti Zuhriyyah Musthofa \\ Balai Besar Riset Perikanan Budidaya Laut \\ Jl. Br. Gondol, Kec. Gerokgak, Kab. Buleleng, Kotak Pos 140, Singaraja, Bali 81101 \\ E-mail: tiaspriyono@yahoo.com
}

(Naskah diterima: 11 Juni 2010; Disetujui publikasi: 2 November 2010)

\begin{abstract}
ABSTRAK
Upaya kontinuitas produksi benih ikan cobia, Rachycentron canadum telah dilakukan namun besarnya biaya operasional dalam penggunaan artemia sebagai pakan masih menjadi faktor pembatas. Oleh karena itu, perlu dilakukan penelitian penundaan pemberian artemia dengan tujuan untuk mengetahui waktu yang tepat saat awal diberikan artemia sehingga penggunaannya efektif dan efisien. Penelitian dilakukan dengan menggunakan wadah berupa bak fiber $\left(1 \mathrm{~m}^{3}\right)$ berjumlah 9 unit yang diisi telur cobia sebanyak 3.000 butir/bak dan larva dipelihara hingga mencapai ukuran benih ( $\pm 3 \mathrm{~cm} /$ umur 20 hari). Rancangan penelitian adalah acak lengkap yang terdiri atas 3 perlakuan yaitu perbedaan waktu awal pemberian artemia yakni pada larva (A) umur 5 hari; (B) umur 10 hari; dan (C) umur 15 hari. Masing-masing perlakuan diulang 3 kali. Data pertumbuhan dan sintasan dianalisis menggunakan sidik ragam. Performansi fisik dan perkembangan tulang belakang diamati sebagai data pendukung. Hasil penelitian menunjukkan bahwa pertumbuhan panjang, bobot, ataupun sintasan di antara perlakuan secara statistik tidak menunjukkan perbedaan yang nyata $(P>0,05)$. Namun pemberian artemia pada larva umur 5 hari (perlakuan A) menghasilkan pertumbuhan panjang $(28 \mathrm{~mm})$ dan bobot badan $(74,067 \mathrm{mg})$ serta sintasan $(12,07 \%)$ relatif lebih tinggi daripada perlakuan B ataupun C. Penundaan pemberian artemia lebih dari 5 hari justru menghasilkan benih yang bertumbuh lebih lambat dan banyak mengalami kematian. Hasil pengamatan terhadap perkembangan tulang belakang pada semua perlakuan tidak menunjukkan performansi tulang belakang yang abnormal.
\end{abstract}

KATA KUNCI: nauplii Artemia, penundaan pakan, performansi benih

ABSTRACT: The effects of suspended feeding time on the performance of cobia (Rachycentron canadum) seed reared in controlled tank. By: Titiek Aslianti, Afifah, and Siti Zuhriyyah Musthofa

The effort to guarantee a sustainable seed production of cobia, Rachycentron canadum have been carried out but the weight of operational cost in the use of artemia as food has been a problem. The aim of the experiment was to describe the exact and effective time for the initial feeding of seed of cobia using Artemia nauplii. Nine concrete tanks with $1 \mathrm{~m}^{3}$ capacity were stocked with cobia eggs at a density 3,000 eggs/tank. The larvae were reared up to juvenile $( \pm 3 \mathrm{~cm} / 20$ days after hatching). In order to improve the growth and increase survival rate, three different initial feeding times of Artemia nauplii have been conducted namely: (A) 5 days after hatching (DAH); (B) $10 \mathrm{DAH}$; and (C) $15 \mathrm{DAH}$. The experiment was conducted in triplicates per treatment. A complete randomized design was used in the study and data of growth rate and survival rate were analyzed using ANOVA. The result showed 
that the different times of the initial feeding of cobia seed using Artemia nauplii were not significant $(P>0.05)$ for the growth and survival rate. However TL $(28 \mathrm{~mm}), B W$ (74.067 mg), and SR (12.07\%) of the treatment $A(5 D A H)$ were higher than those in treatment $B(10 D A H)$ or treatment $C(15 D A H)$. The suspension of Artemia nauplii application for more than 5 days will slow down the growth and increased the mortality of the seed. None of the treatments have caused deformity backbones growth of the seed.

\section{KEYWORDS: Artemia nauplii, fry performance, lasted time feeding}

\section{PENDAHULUAN}

Ikan cobia (Rachycentron canadum) merupakan ikan sub tropis maupun tropis yang budidayanya banyak dikembangkan di beberapa negara seperti Taiwan, Vietnam, Texas, Amerika, dan Australia. Di Indonesia penelitian ikan cobia mulai dirintis tahun $2003 / 2004$, dan diharapkan bisa menjadi komoditas andalan budidaya karena merupakan satu-satunya dari famili Rachycentridae yang bertumbuh sangat cepat dan memiliki kualitas daging yang bagus sehingga banyak diminati terutama untuk produk fillet (Arnold et al., 2002). Pembenihan ikan cobia sudah dilakukan di Balai Besar Riset Perikanan Budidaya Laut (BBRPBL), Gondol-Bali, namun produksi benih yang dihasilkan masih fluktuatif mengingat dalam pemeliharaan larva masih mengandalkan pakan alami berupa fitoplankton (Nannochloropsis) dan zooplankton (rotifer dan copepoda), serta nauplii Artemia. Nampaknya artemia merupakan pakan alami yang mutlak diperlukan bagi larva ikan-ikan karnivora seperti halnya larva kerapu macan (Epinephelus fuscoguttatus), kerapu bebek (Cromileptes altivelis), kakap (Lutjanus sp.), kuwe (Gnathanodon speciosus) dan juga larva ikan cobia (Rachycentron canadum). Dilaporkan oleh Sorgeloos et al. (1986) bahwa Artemia salina (brine shrimp) termasuk jenis krustase tingkat rendah dari filum Arthropoda yang mengandung protein cukup tinggi sekitar 40\%-62,78\% sehingga sering digunakan sebagai jasad pakan alami pada pembenihan ikan-ikan bersirip dan krustase seperti udang, kepiting, dan rajungan. Keunggulan artemia sebagai jasad pakan alami di antaranya adalah bernilai gizi tinggi, praktis dalam penggunaan, mempunyai ukuran relatif kecil dan sesuai dengan ukuran bukaan mulut larva, gerakannya lambat sehingga mudah dimangsa oleh larva ikan/udang, dan dapat digunakan sebagai pembawa nutrien juga senyawa tertentu sebagai obat dan hormon bahkan pewarna (Soni, 1998 dalam Poernomo et al.,
1999). Namun demikian mengingat kebutuhan artemia dalam satu periode pemeliharaan larva ikan cobia sangat banyak, dan artemia masih merupakan produk impor serta tidak semua strain kista artemia dapat menjamin nutrisinya selama pemeliharaan larva, maka hal tersebut akan menjadi kendala dalam upaya produksi benih secara massal yang tentunya akan meningkatkan biaya operasional. Selain itu, larva yang memanfaatkan pakan artemia dalam jumlah banyak atau berlebihan dikhawatirkan akan menyebabkan terjadinya deformitas (pertumbuhan abnormal) terutama pada terbukanya tutup insang dan pertumbuhan yang tidak seragam serta memicu pertumbuhan tulang belakang yang abnormal (lordosis/ skoliosis). Di sisi lain dengan pemberian artemia lebih awal dikhawatirkan dapat menyebabkan terjadinya blooming pakan dalam bak pemeliharaan yang diduga akan menimbulkan masalah baru yaitu tumbuhnya bakteri patogen yang dapat mengganggu pertumbuhan fisik larva dan berdampak terhadap gagalnya upaya produksi benih.

Berdasarkan permasalahan tersebut, maka perlu dilakukan penelitian penundaan pemberian artemia sebagai pakan selama pemeliharaan larva hingga dihasilkan benih yang memiliki performansi proporsional (ukuran standar, normal, dan tidak cacat). Tujuan penelitian adalah untuk mengetahui waktu yang tepat saat awal diberikan artemia sehingga penggunaannya efektif dan efisien serta dapat menekan biaya operasional. Diharapkan bahwa teknologi pembenihan ikan cobia di masa datang dapat diaplikasikan ke masyarakat petani dalam bentuk Hatcheri Skala Rumah Tangga (HSRT).

\section{BAHAN DAN METODE}

Penelitian dilakukan di hatcheri ikan laut BBRPBL, Gondol. Wadah yang digunakan berjumlah sembilan unit bak fiber bentuk silinder berkapasitas $1 \mathrm{~m}^{3}$ yang bagian dalamnya dicat warna kuning dan bagian luar 
dicat warna hitam. Setiap bak diisi air laut $( \pm$ 34 ppt) sebanyak $600 \mathrm{~L}$ dan dilengkapi dengan aerasi yang pengudaraannya diatur merata melalui stop kran aerasi sehingga oksigen tersebar ke seluruh bagian bak. Telur ikan cobia sebagai bahan uji berasal dari hasil pemijahan alami induk-induk yang dipelihara secara terkontrol dalam bak berkapasitas 100 $\mathrm{m}^{3}$. Telur yang fertil ditebar ke dalam masingmasing bak pemeliharaan larva dengan kepadatan 3.000 butir/bak.

Setelah telur menetas, cangkang telur dibersihkan dengan cara menyipon bagian dasar bak. Selanjutnya jumlah telur yang menetas dihitung untuk mengetahui daya tetasnya. Menjelang larva berumur 2 hari $\left(D_{2}\right)$ diberikan plankton Nannochloropsis oculata

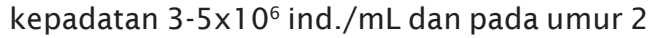
hari $\left(D_{2}\right)$ sampai umur 10 hari $\left(D_{10}\right)$ diberikan pakan awal berupa rotifer dengan kepadatan 10-15 ind./mL. Setelah $D_{10}$ larva mulai diberi pakan buatan (powder) sebanyak 5-10 g/bak/ hari dengan cara menaburkan langsung di atas permukaan air pemeliharaan hingga larva berumur 20 hari $\left(D_{20}\right)$. Selanjutnya nauplii Artemia dengan kepadatan 0,5-1 ind./mL/hari diberikan dengan selang waktu berbeda yang merupakan perlakuan yaitu mulai larva berumur (A) 5 hari; (B) 10 hari; dan (C) 15 hari. Selama penelitian, semua pakan diberikan sebanyak satu kali per hari pada pagi hari. Pergantian air dilakukan secara flow-through (air mengalir terus-menerus) dengan cara mengatur kran pemasukan (inlet) dan pengeluaran (outlet) air pada setiap bak mulai larva berumur 10 hari sampai menjelang panen (umur 20 hari) dengan jumlah bertahap mulai 10\% sampai 100\% disesuaikan dengan perkembangan larva. Pergantian air dihentikan selama \pm 1 jam saat dilakukan pemberian pakan. Hal ini untuk mengantisipasi agar pakan tidak ikut terbuang bersama air pengeluaran juga memberikan kesempatan larva memperoleh pakan.

Untuk melihat pengaruh perlakuan terhadap performansi larva dilakukan pengamatan terhadap panjang total (TL) dan bobot badan (BW) setiap 3 hari, sedangkan sintasan dihitung pada akhir penelitian saat larva berumur 20 hari dan telah mencapai fase yuwana. Penelitian menggunakan rancangan acak lengkap dengan tiga kali ulangan. Semua data yang diperoleh dihimpun dalam bentuk tabulasi dan dianalisis secara ANOVA untuk mengetahui adanya perbedaan di antara perlakuan.
Adapun pengamatan terhadap perkembangan tulang belakang larva dilakukan untuk mendukung pengamatan secara visual melalui teknik pewarnaan tulang belakang dengan menggunakan metode pewarnaan ganda (double stainning method) menurut Potthof (1984), sekaligus untuk mengetahui tingkat deformitasnya. Pengambilan sampel dilakukan secara acak dari masing-masing perlakuan sebanyak 10-15 ekor yang dimulai pada $D_{5}-D_{10}$, kemudian $D_{12}$ hingga $D_{20}$ dengan selang waktu 2 hari. Setelah sampel melalui proses pewarnaan, selanjutnya satu per satu sampel diamati tentang jumlah total ruas tulang belakang (JTRTB) dan panjang ruas tulang belakang (PRTB) dengan menggunakan mikroskop merk Nikon Eclipse E400 pembesaran 10-20X, sedangkan panjang tulang belakang (PTB) dan deformitas diamati dengan menggunakan mikroskop merk Nikon Eclipse E600 pembesaran 2-10X. Dokumentasi gambar dilakukan melalui pemotretan dengan program ACT-1 dan pengukuran sampel pada gambar dilakukan dengan menggunakan program Win Roof V 5.0. Selanjutnya data pertumbuhan dianalisis dengan menggunakan program SPSS 13.00.

Parameter pendukung yang diamati dalam penelitian ini adalah kualitas air dan perkembangan bakteri pada media pemeliharaan. Pengamatan kualitas air dilakukan 3 kali sehari yakni pada pagi ( \pm pukul 09.00 WITA), siang ( \pm pukul 14.00 WITA), dan sore ( \pm pukul 17.00 WITA) hari untuk mengetahui fluktuasi kualitas air harian. Parameter tersebut meliputi suhu (maksimum-minimum), oksigen terlarut, $\mathrm{pH}$, nitrit, dan amonia yang dapat diacu apabila ditemukan hal-hal yang ekstrim seperti munculnya penyakit, bakteri ataupun virus yang dikhawatirkan dapat mengganggu sintasan larva.

\section{HASIL DAN BAHASAN}

\section{Pertumbuhan dan Sintasan Larva}

Hasil pengamatan terhadap pertumbuhan panjang total (TL) dan bobot badan (BW) larva yang diamati setiap 3 hari selama masa pemeliharaan hingga mencapai umur 20 hari $\left(\mathrm{D}_{20}\right)$ disajikan pada Gambar 1. Sedangkan ukuran panjang total, bobot badan, dan sintasan pada akhir penelitian $\left(D_{20}\right)$ tertera pada Tabel 1, serta performansi benih pada saat panen disajikan pada Gambar 2. 

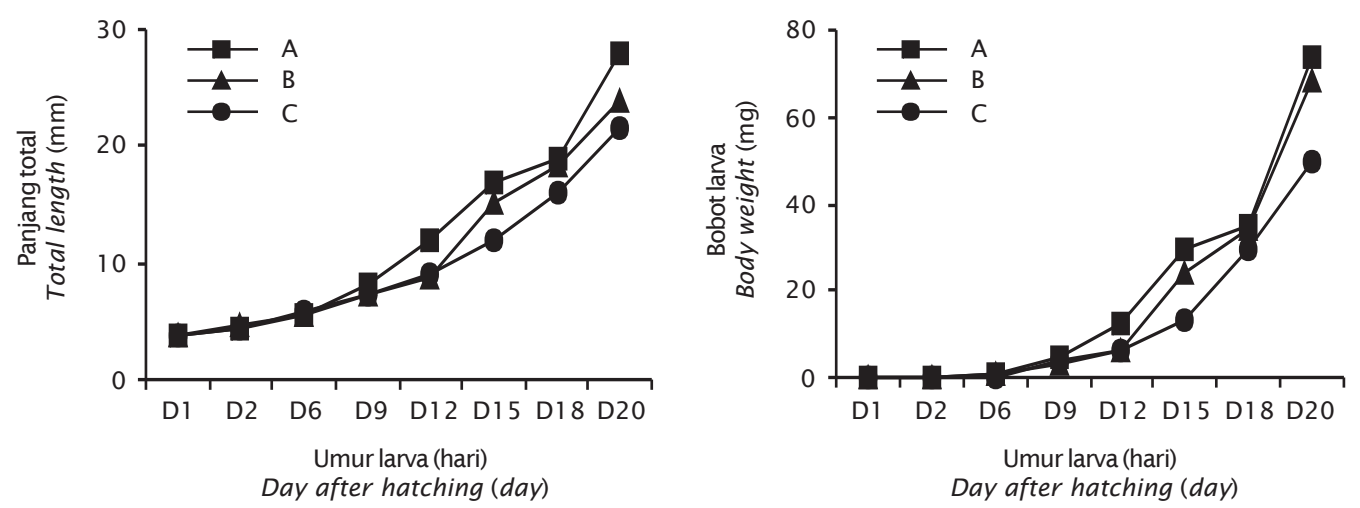

Gambar 1. Pertumbuhan panjang total dan bobot badan larva selama penelitian

Figure 1. Growth rate (TL and BW) of larvae during the experiment

Dari Gambar 1 menunjukkan bahwa pertumbuhan panjang total dan bobot badan larva pada perlakuan A tampak mulai meningkat pada hari ke- $9\left(D_{9}\right)$ dan terus berlanjut hingga $D_{20}$. Sementara pada perlakuan $B$ dan $C$ mengalami pertumbuhan yang relatif sama dan mulai meningkat pada $D_{15}$. Walaupun secara statisik di antara ketiga perlakuan tidak menunjukkan perbedaan yang nyata $(P>0,05)$, namun perlakuan $A$ yakni dengan pemberian nauplii Artemia pada $D_{5}$, ternyata mampu menghasilkan nilai pertumbuhan relatif lebih tinggi (TL 28 mm dan BW 74,07 mg) dengan performansi benih yang lebih besar dibanding perlakuan B (TL $24 \mathrm{~mm}$ dan BW 68,54 mg) ataupun perlakuan C (TL 21,53 $\mathrm{mm}$ dan BW 49,95 mg) (Gambar 2).

Dengan demikian dapat dikatakan walaupun larva ikan cobia telah mampu mengkonsumsi nauplii Artemia pada $\mathrm{D}_{2}$ (Liao \& Leano, 2005), tetapi dapat dilakukan penundaan hingga $D_{5}$ dan ternyata menghasilkan pertumbuhan yang cukup baik. Penundaan artemia sebagai pakan selama 3 hari pemeliharaan $\left(D_{2}\right.$ sampai $\left.D_{5}\right)$ dinilai cukup efisien dan dapat menekan biaya operasional, terlebih jika produksi benih cobia dilakukan secara massal. Namun demikian penundaan pemberian artemia setelah $D_{5}$ yakni pemberian pada $D_{10}$ dan $D_{15}$ justru menghasilkan nilai

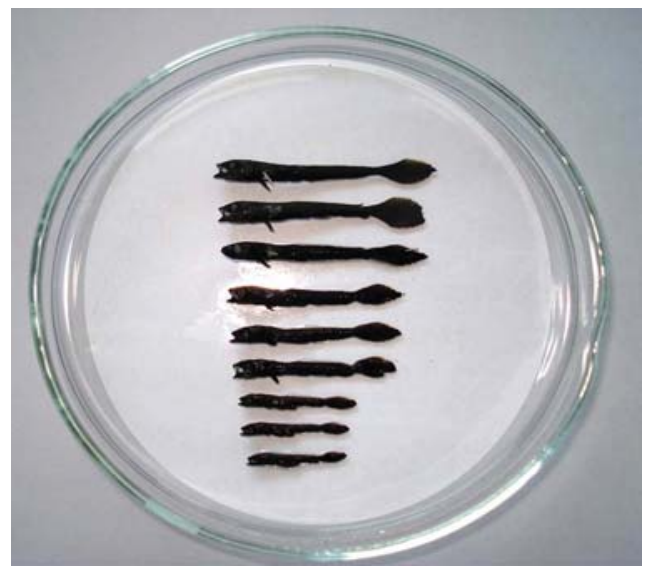

Gambar 2. Performansi tumbuh (TL) perlakuan $\mathrm{A}, \mathrm{B}$, dan $\mathrm{C}$ pada $\mathrm{D}_{20}$

Figure 2. Growth performance of treatment $A, B$, and $C$ on $D_{20}$ 
Tabel 1. Rata-rata pertumbuhan panjang, bobot badan, dan sintasan benih ikan cobia pada saat penelitian berakhir $\left(D_{20}\right)$

Table 1. The average of growth rate and survival rate of cobia seed at the end of the research $\left(D_{20}\right)$

\begin{tabular}{cccc}
\hline $\begin{array}{c}\text { Perlakuan } \\
\text { Treatment }\end{array}$ & $\begin{array}{c}\text { Panjang total } \\
\text { Total length } \\
(\mathbf{m m})\end{array}$ & $\begin{array}{c}\text { Bobot badan } \\
\text { Bodyweight } \\
(\mathbf{m g})\end{array}$ & $\begin{array}{c}\text { Sintasan } \\
\text { Survival rate } \\
(\%)\end{array}$ \\
\hline A & $28.00 \pm 3.93^{\mathrm{a}}$ & $74.07 \pm 15.08^{\mathrm{a}}$ & $12.07 \pm 5.16^{\mathrm{a}}$ \\
B & $24.00 \pm 1.22^{\mathrm{a}}$ & $68.54 \pm 19.99^{\mathrm{a}}$ & $11.35 \pm 1.57^{\mathrm{a}}$ \\
C & $21.53 \pm 1.86^{\mathrm{a}}$ & $49.95 \pm 13.19^{\mathrm{a}}$ & $10.98 \pm 2.94^{\mathrm{a}}$ \\
\hline
\end{tabular}

* Angka pada kolom yang diikuti huruf yang sama tidak menunjukkan perbedaan yang nyata $(\mathrm{P}>0.05)$

The values in the coloum followed by similar letter are not significantly different $(P>0.05)$

pertumbuhan dan sintasan yang lebih rendah (Tabel 1).

Dari penelitian yang pernah dilakukan sebelumnya telah dilaporkan bahwa ikan cobia merupakan ikan yang mempunyai pertumbuhan sangat cepat dibandingkan spesies ikan lainnya (Liao \& Leano, 2005; Arnold et al., 2002; Priyono et al., 2005). Dengan pertumbuhan yang demikian, maka selama pemeliharaan larva tentunya harus diimbangi dengan pemberian pakan yang tepat, baik secara kualitas (nutrisi), kuantitas maupun waktu pemberiannya. Artemia salina merupakan jenis krustase tingkat rendah yang naupliusnya sebagai pakan alami utama dapat diberikan pada larva ikan cobia muda sebagai penunjang kebutuhan nutrisi, baik untuk pertumbuhan maupun sintasannya. Dilaporkan oleh Liao \& Leano (2005) yang menyatakan bahwa untuk menghindari tingginya mortalitas, maka dalam pemeliharaan larva cobia artemia sudah harus diberikan saat larva berumur 2 hari. Namun demikian, selama ini diketahui bahwa pemberian nauplii Artemia masih terkendala pada tingginya harga kista, potensi abnormalitas serta potensi sebagai agen pembawa penyakit khususnya vibrio pada media pemeliharaan (Redjeki \& Sunyoto, 1992). Dengan demikian pemberian artemia pada hari ke-5 dinilai merupakan waktu yang tepat yang dapat menunjang pertumbuhannya.

Dari pengamatan terhadap tingkat sintasan (Tabel 1) menghasilkan nilai yang berbanding lurus dengan nilai pertumbuhan yakni sintasan pada perlakuan A lebih tinggi $(12,07 \%)$ dari pada perlakuan $\mathrm{B}(11,35 \%)$ ataupun $\mathrm{C}(10,98 \%)$, sebagaimana tersaji pada Gambar 3. Hal ini menunjukkan bahwa penggunaan artemia pada $D_{5}$ merupakan waktu yang tepat saat awal larva memerlukan asupan pakan dengan nutrisi yang cukup guna memacu pertumbuhan. Pertumbuhan yang baik pada gilirannya dapat memacu sintasan yang lebih baik pula. Menurut Stappen (1967) dalam Lavens \& Sorgeloos (1996), secara umum nauplii Artemia mengandung protein antara $41 \%-47 \%$, karbohidrat $\pm 11 \%$, dan lemak antara $21 \%-23 \%$. Ditambahkan oleh Treece (2000) bahwa 3\%$15 \%$ dari kandungan lemak pada artemia adalah berupa $n-3$ highly unsaturated fatty acids/ HUFA (asam lemak tak jenuh), yang terdiri atas Ecosa Pentaenoic Acid (EPA), Doco Hexaenoic Acid (DHA), dan Arachidonic Acid (ARA) yang sangat berpengaruh terhadap pertumbuhan, perkembangan organ, dan sintasan larva ikan laut. Bahkan apabila kandungan HUFA makin rendah, dapat menyebabkan peningkatan mortalitas pada larva.

\section{Analisis Pertumbuhan Tulang Belakang}

Dalam proses pewarnaan tulang belakang, diketahui bahwa larva ikan cobia mempunyai lapisan daging yang lebih tebal dibanding larva jenis ikan lain, sehingga proses pewarnaan tulang memerlukan waktu cukup lama ( \pm 3 minggu).

Berdasarkan hasil pengamatan diketahui bahwa secara umum pertumbuhan panjang badan larva ikan cobia sejalan dengan pertumbuhan tulang belakang. Hal ini terjadi pada ketiga perlakuan yang diuji, dengan 


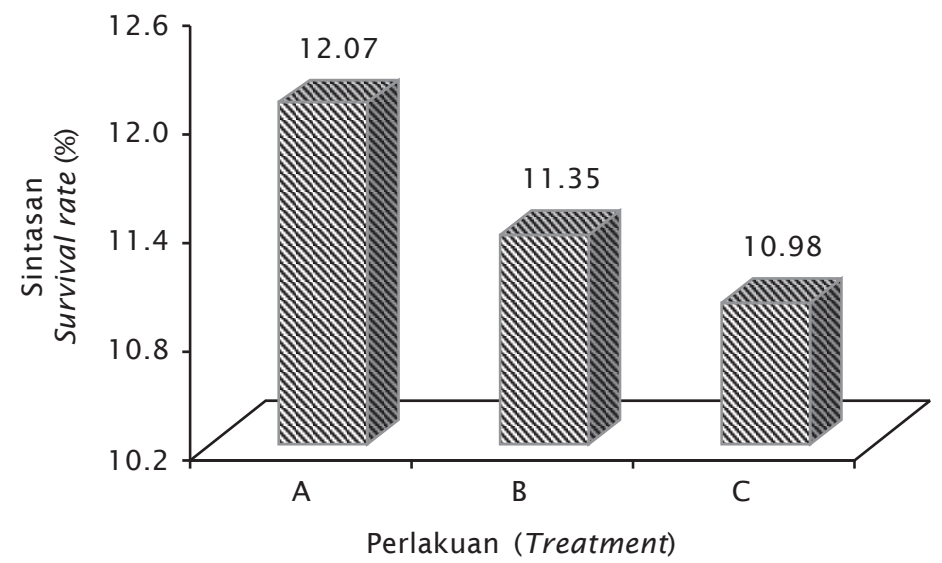

Gambar 3. Hasil pengamatan terhadap sintasan benih pada saat penelitian berakhir (umur 20 hari)

Figure 3. Survival rate (\%) of the seed at the end of the research (20 DAH)

pertumbuhan yang sistematik sampai pada akhir masa pemeliharaan larva. Selama masa pemeliharaan larva hingga $D_{20}$, dari ketiga perlakuan didapatkan pola pertumbuhan yang sama. Diskripsi rinci perkembangan tulang belakang dari masing-masing perlakuan dijelaskan pada Tabel 2.

Dari hasil pengamatan melalui mikroskop terhadap perkembangan tulang belakang larva pada $\mathrm{D}_{20}$ dari masing-masing perlakuan (Gambar 4), menunjukkan bahwa perkembangan tulang belakang larva yang diberi pakan artemia lebih awal (perlakuan A) menghasilkan performansi tulang belakang lebih cepat menjadi tulang keras (bone) yang ditandai dengan warna merah dibanding perlakuan $B$ dan $C$ yang masih menunjukkan perkembangan tulang belakang pada fase peralihan (transisi) dari tulang rawan (cartilage) menjadi tulang keras (bone).

Dari semua sampel larva yang diamati (A, B, dan C) mulai umur 5 hingga 20 hari ditemukan beberapa ekor larva (perlakuan A) dengan bentuk tulang belakang yang abnormal (deformity) yaitu pelekukan tulang ekor (notochord) pada $\mathrm{D}_{16-20}$ (Gambar 5a) dan penebalan tulang (perlakuan $C$ ) pada $D_{20}$ (Gambar 5b). Tidak ditemukannya sampel dengan tulang belakang yang abnormal pada perlakuan B bukan berarti lebih baik tetapi diduga lebih disebabkan oleh keterbatasan pengambilan sampel yang kurang mewakili semua hewan uji serta keterbatasan pengamatan tulang belakang. Selain itu, ketidaknormalan sampel pada perlakuan A dan $C$ tidak sampai berpengaruh terhadap performansi fisik dan jumlahnya hanya beberapa ekor sehingga dapat dikatakan bahwa pertumbuhan tulang belakang pada semua perlakuan masih termasuk kategori baik.

Penundaan artemia sebagai pakan tidak berpengaruh langsung terhadap ketidaknormalan tulang belakang, tetapi lebih berpengaruh terhadap pertumbuhan yang cenderung lebih lambat. Salah satu faktor yang cukup berpengaruh dalam perkembangan tulang belakang larva ikan laut adalah kandungan nutrisi pakan (di antaranya adalah protein, vitamin, dan kalsium) yang diberikan selama masa pemeliharaan. Dilaporkan oleh Kitajima et al. (1994) dalam Aslianti (2005) bahwa kekurangan nutrisi pada larva akan mengakibatkan lambatnya pertumbuhan maupun perkembangan tulang belakang. Bahkan dikatakan oleh Lall (2007) yang menyatakan bahwa kekurangan nutrisi pakan dapat meningkatkan lordosis pada larva ikan red sea bream, kyphosis, scoliosis, dan platyspondily (pemendekan dan penipisan pada tulang belakang).

\section{Pengamatan Kualitas Air dan Bakteri}

Hasil pengamatan menunjukkan bahwa kualitas air selama masa pemeliharaan larva terlihat masih berada dalam batas yang bisa ditoleransi oleh larva ikan cobia (Tabel 3). Kondisi tersebut masih terjaga karena selama 


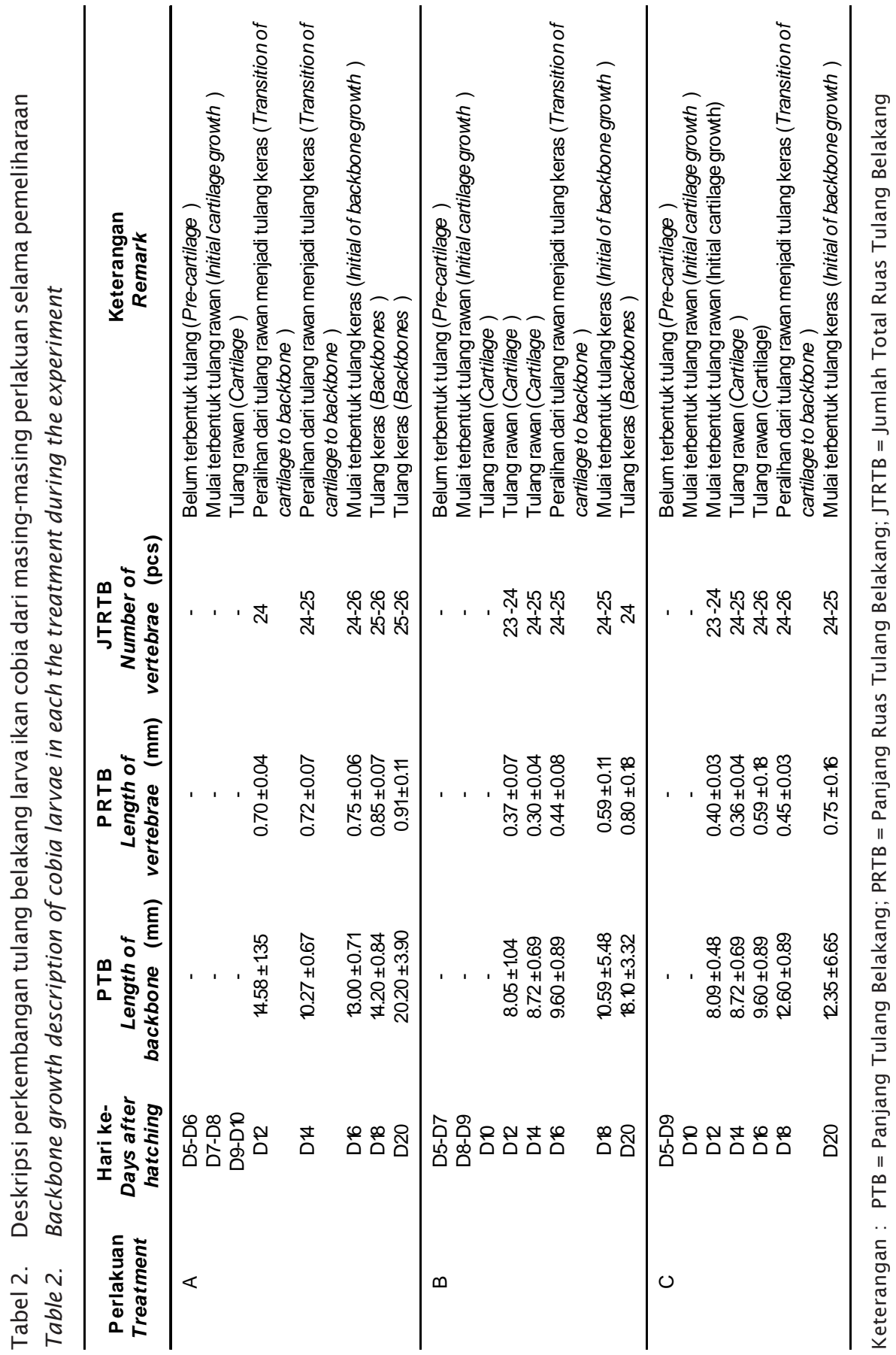



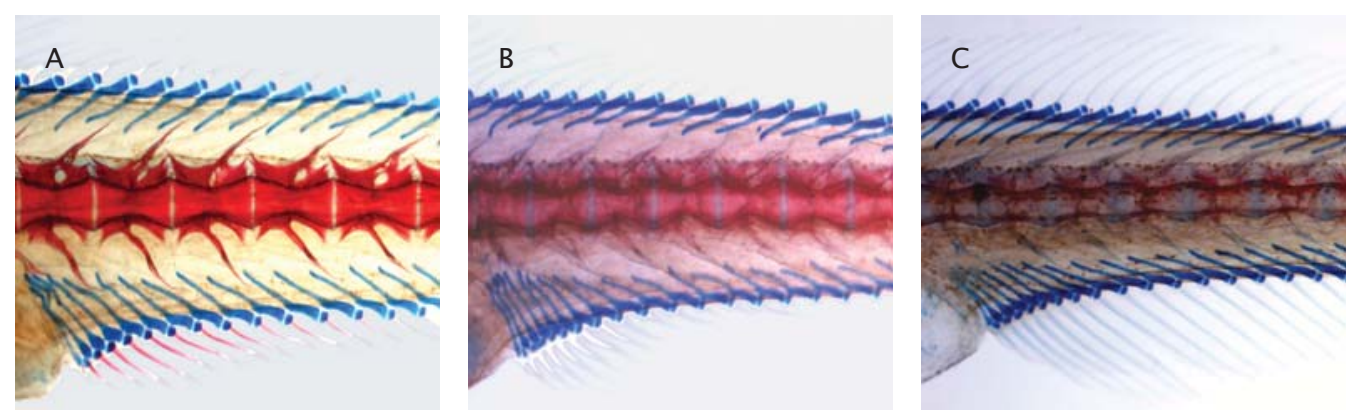

Gambar 4. Perkembangan tulang belakang larva ikan cobia dari masing-masing perlakuan pada $\mathrm{D}_{20}$

Figure 4. The backbone growth of cobia larvae in each the treatment at $D_{20}$

masa pemeliharaan, pergantian air, dan penyiponan dasar bak dilakukan secara kontinu setiap hari mulai dari $D_{10}$ hingga $D_{20}$. Hal ini juga untuk mengantisipasi agar tidak terjadi akumulasi sisa pakan yang dapat membahayakan bagi sintasan larva.

Adapun pengamatan terhadap perkembangan bakteri selama masa pemeliharaan tertera pada Tabel 4. Kepadatan bakteri khususnya vibrio terlihat masih pada kisaran batas normal. Menurut Austin (1988), total bakteri pada suatu media pemeliharaan dikatakan masih dalam batas normal jika berkisar antara $10^{3}-10^{6} \mathrm{cfu} / \mathrm{mL}$ dan total bakteri vibrio berkisar antara $10^{2}-10^{3} \mathrm{cfu} / \mathrm{mL}$. Munculnya bakteri dalam wadah pemeliharaan larva diduga selain berasal dari air pemeliharaan yang juga merupakan media hidup berbagai mikroorganisme air baik yang patogen maupun non patogen, juga dari pakan alami yang diberikan. Keberadaan nauplii
Artemia sebagai ransum pakan sering kali merupakan penyebab munculnya parasit (bakteri) yang mengakibatkan kematian larva. Dari hasil pengamatan, bakteri mulai muncul ketika larva berumur 7 hari yang ditandai dengan munculnya bercak berwarna kemerahan pada lapisan dasar wadah pemeliharaan. Dikatakan oleh Roza et al. (1998), bahwa Vibrio harveyi penyebab bercak merah mempunyai karakteristik yang berbeda dibanding Vibrio harveyi penyebab penyakit kunang-kunang. $V$. harveyi penyebab penyakit kunang-kunang tidak mampu mensintesa sukrosa sehingga koloninya berwarna hijau pada media TCBSA dan menghasilkan cahaya, sedang $V$. harveyi penyebab bercak merah mampu mensintesa sukrosa sehingga koloninya berwarna kuning dan tidak bercahaya. Keadaan tersebut memungkinkan timbulnya penyakit yang dapat mengganggu kehidupan larva. Oleh karenanya hal ini secepatnya diantisipasi dengan cara
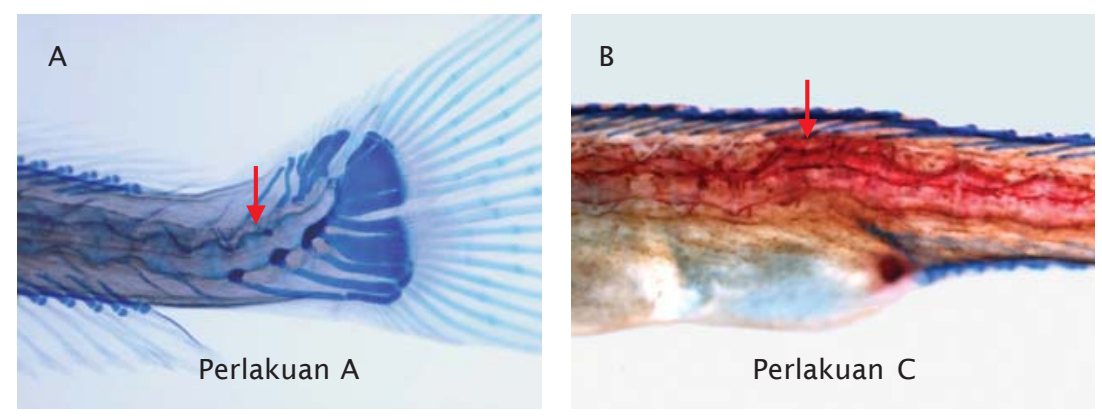

Gambar 5. (a) Pelekukan tulang ekor yang terjadi pada perlakuan $A$ umur $D_{16-20}$, dan (b) penebalan tulang belakang pada perlakuan $C$ umur $D_{20}$

Figure 5. (a) Caudal bone deformity of treatment $A$ on $D_{16-20}$ and (b) backbone deformity of treatment $C$ on $D_{20}$ 
Tabel 3. Hasil pengamatan kualitas air selama penelitian

Table 3. Variations of water quality during the experiment

\begin{tabular}{lccc}
\hline \multicolumn{1}{c}{$\begin{array}{c}\text { Parameter } \\
\text { Parameters }\end{array}$} & \multicolumn{3}{c}{ Waktu (Time) } \\
\cline { 2 - 4 } & $\begin{array}{c}\text { Pagi } \\
\text { Morning }\end{array}$ & $\begin{array}{c}\text { Siang } \\
\text { Midday }\end{array}$ & $\begin{array}{c}\text { Sore } \\
\text { Aft ernoon }\end{array}$ \\
\hline $\begin{array}{l}\text { Suhu } \\
\text { Temperature }\left({ }^{\circ} \mathrm{C}\right)\end{array}$ & $28.4-29.6$ & $29.7-30.5$ & $30.1-30.7$ \\
$\mathrm{pH}$ & $8.08-8.41$ & $8.19-8.5$ & $8.15-8.45$ \\
Salinitas & $30-37$ & $30-35$ & $30-38$ \\
$\begin{array}{l}\text { Salinity (ppt) } \\
\text { Oksigen te rlarut }\end{array}$ & $5.2-7.0$ & $5.1-7.5$ & $5.2-6.4$ \\
$\begin{array}{l}\text { DO (mg/L) } \\
\text { Intensitas cahaya }\end{array}$ & $1,800-8,300$ & $1,750-23,300$ & $365-9,570$ \\
Intensity (luxs) & & $0.0011-0.450$ & \\
$\mathrm{NH}_{3}$ (mg/L) & & $0.0004-0.258$ & \\
$\mathrm{NO}_{2}$ (mg/L) & & & \\
\hline
\end{tabular}

Tabel 4. Hasil pengamatan kisaran jumlah total bakteri, Vibrio spp. ,dan Vibrio harveyi selama penelitian larva ikan cobia

Table 4. Ranges of total bacterial, Vibrio spp. ,and Vibrio harveyi during the experiment

\begin{tabular}{cccc}
\hline $\begin{array}{c}\text { Sampel } \\
\text { Sample }\end{array}$ & $\begin{array}{c}\text { Total bakteri } \\
\text { Total bacteri } \\
(\mathbf{c f u} / \mathrm{mL})\end{array}$ & $\begin{array}{c}\text { Vibrio spp. } \\
(\mathbf{c f u} / \mathrm{mL})\end{array}$ & $\begin{array}{c}\text { Vibrio harveyi } \\
(\mathbf{c f u} / \mathrm{mL})\end{array}$ \\
\hline $\mathrm{A}$ & $1.5 \times 10^{4}-6.4 \times 10^{4}$ & $1.0 \times 10^{3}-6.4 \times 10^{3}$ & $\mathrm{TT}-1.4 \times 10^{3}$ \\
B & $6.4 \times 10^{3}-5.2 \times 10^{4}$ & $1.2 \times 10^{2}-4.2 \times 10^{3}$ & $\mathrm{TT}-1.0 \times 10$ \\
C & $2.2 \times 10^{4}-4.1 \times 10^{4}$ & $1.7 \times 10^{2}-5.5 \times 10^{3}$ & TT $-2.0 \times 10$ \\
\hline
\end{tabular}

menyipon dasar wadah juga pemberian desinfektan (Erubazu) pada nauplii Artemia sebelum diberikan sebagai pakan larva. Nampaknya dengan cara antisipasi seperti tersebut peningkatan jumlah bakteri dalam bak pemeliharaan dapat dihindari dan larva masih bisa diselamatkan hingga berumur 20 hari saat penelitian berakhir.

\section{KESIMPULAN}

Hasil penelitian menunjukkan bahwa pertumbuhan panjang (TL), bobot (BW), dan sintasan (SR) di antara perlakuan secara statistik tidak ada perbedaan yang nyata. Namun pemberian artemia pada larva umur 5 hari memperlihatkan performansi tumbuh, perkembangan tulang belakang, dan sintasan yang lebih baik. Penundaan pemberian artemia lebih dari 5 hari justru menghasilkan benih yang bertumbuh lebih lambat dan banyak mengalami kematian.

\section{UCAPAN TERIMA KASIH}

Terima kasih yang tak terhingga disampaikan kepada staf teknisi litkayasa bidang larval rearing (Muslim Romdlianto dan Agus Supriyatna), juga staf teknisi kualitas air (Ni Putu Ayu Kenak dan Kadek Ani) atas peran serta dan kerja samanya dalam membantu pelaksanaan penelitian ini hingga selesai.

\section{DAFTAR ACUAN}

Arnold, C.R., Kaiser, J.B., \& Holt, G.J. 2002. Spawning of cobia Rachycentron canadum in captivity. J. of the World Aquaculture Society, 33(2): 205-207. 
Aslianti, T. 2005. Evaluasi kualitas benih ikan kerapu macan (Epinephelus fuscoguttatus) produksi beberapa hatchery di Bali berdasarkan pengamatan pertumbuhan tulang belakang. J. Perik. Fakultas Teknologi Kelautan dan Perikanan. Universitas Hang Tuah Surabaya, I(2): 56-62

Austin, B. 1988. Marine Microbiology. Cambridge University Press. Great Britain, 222 pp.

Lall, S.P. 2007. Comparative mineral nutrition of fish: sources and requirements. Academic Press, San Diego, CA, USA, p. 220252.

Lavens, P. \& Sorgeloos, P. 1996. Manual on the production and use of live food for aquaculture. FAO Fisheries Technical Paper. No. 361. Rome, FAO, 295 pp.

Liao, I.C. \& Leano, E.M. 2005. Cobia aquaculture in Taiwan. World Aquaculture, 36(1): 4.

Potthof, T. 1984. Clearing and staining techniques in ontogeny and systematic of fishes (Ed.) by Moser, H.G. et al. special publication I. American society of ichthyologist and herpetologist, p. 35-37.

Poernomo, A., Murniyati, \& Utomo, B.S.B. 1999. Penyediaan Artemia lokal untuk mendukung budidaya laut dan pantai. Prosiding Seminar Nasional Penelitian dan Diseminasi Teknologi Budidaya Laut dan
Pantai. Jakarta, 2 Desember 1999, hlm. 330332.

Priyono, A., Slamet, B., \& Sutarmat, T. 2005. Pengamatan beberapa aspek biologi ikan cobia (Rachycentron canadum) dari perairan Bali Utara. Prosiding Seminar Nasional Tahunan Hasil Penelitian Perikanan dan Kelautan. Yogyakarta, 30 Juli 2005. Bidang MSP, hlm. 87-93.

Redjeki, S. \& Sunyoto, P.1992. Pengaruh waktu pemberhentian pemberian nauplius Artemia terhadap sintasan larva Kakap Putih, Lates calcarifer. Balai Penelitian Perikanan Budidaya Pantai, Maros. J. Pen. Budidaya Pantai, 8(5): 27-32.

Roza, D., Zafran, \& Koesharyani, I. 1998. Studi tentang organisme penyebab bercak merah pada bak pemeliharaan larva udang windu, Penaeus monodon. J. Pen. Perik. Indonesia, IV(3): 72-77.

Sorgeloos, P., Lavens, P., Leger, P., Tackaert, W., \& Versichele, D. 1986. Hatching efficiency and hatching quality of Artemia cysts. Quality evaluation of Artemia cysts for use as food in aquaculture hatcheries. Manual for the culture and use of brine shrimp Artemia in aquaculture, $35 \mathrm{pp}$.

Treece, G. 2000. Artemia production for marine larval fish culture. Southern Regional Aquaculture Center Publication, (702): 1-8. 